\title{
sciendo
}

\section{The Impact of Internal Knowledge Sharing on Sales Department's Innovativeness and New Product Commercialization}

\author{
Erik RUŽIĆ, Dragan BENAZIĆ \\ Juraj Dobrila University of Pula, Faculty of Economics and Tourism "Dr. Mijo Mirković", Pula, Croatia, \\ erik.ruzic@unipu.hr, dragan.benazic@unipu.hr
}

Background and Purpose: Innovativeness and new product commercialization are highly important for companies. Therefore, a deep understanding of the impact of all potentially influential drivers of success is critical. The purpose of the paper is to explore the impact of internal knowledge sharing on new product selling and sales innovativeness as well as the impact of empowerment on internal knowledge sharing and, indirectly, on new product selling and sales innovativeness.

Design/Methodology/Approach: The research encompassed 101 salespeople working at the top 1000 value added creators in Croatia. The questionnaire was developed and adapted using four scales, to assess internal knowledge sharing, new product selling, sales innovativeness, and empowerment. The data was analyzed by using the PLS-SEM method to examine the relationships between constructs.

Results: As evidenced by the survey results, internal knowledge sharing positively impacts new product selling and sales department's innovativeness, and empowerment is positively linked to internal knowledge sharing and, indirectly, to new product selling and sales department's innovativeness.

Conclusion: Managers should underpin different activities in order to enhance empowerment and internal knowledge sharing with the aim to affect companies' performance in commercialization of a new product and sales department's innovativeness. Future research could include moderator variables between the empowerment construct and the internal knowledge sharing construct and deepen the insight into the type of information shared, the dynamics of sharing and the barriers in the process, and other factors that positively affect knowledge sharing.

Keywords: New product selling, Sales department's innovativeness, Internal knowledge sharing, Empowerment, Salespeople.

\section{Introduction}

Although the failure rate of new products is high, intense global competition and demanding customers put pressure on companies and force them to launch new products (Sharma \& Sagar, 2017). However, 40 to $90 \%$ of all new products fail in the marketplace, causing a substantial financial loss to companies (Borgh \& Schepers, 2017). Yet at the same time, newly launched products and services generate the highest revenues for companies (Petrariu et al., 2013). As a result, despite all obstacles and high potential losses, market circumstances and potential revenues push companies to develop new products. An important stage in the new product development process is the last phase, commercialization, and although successful new product selling is one of the most important missions of a company (Ahearne, et al., 2010), it is also one of the most challenging tasks for salespeople. In fact, they are

Received: 2nd June 2020; revised: 8th March 2021; accepted: 19th March 2021 
not prone to selling a new product; they prefer selling the existing ones (Wieseke et al., 2007).

On the other hand, in a world full of similar and easyto-copy products and services, innovativeness may be a differentiation tool (Healy et al., 2018) for salespeople and a source of competitive advantage. Innovativeness can work well within the sales department and is especially important when a new product is brought to the market and salespeople undertake the challenging task of selling it. In fact, innovativeness within a department is seen as a work environment that encourages employees' innovative behavior within the department itself (Matsuo, 2005).

In order to improve and facilitate the commercialization phase (i.e. new product selling) and to enhance salespeople's creativity and flexibility (i.e. sales innovativeness), it becomes important to investigate the impact of a potentially significant driver of success. In fact, new product selling could be positively affected by knowledge sharing among salespeople as well as between sales force and other departments. Moreover, this openness and readiness to share information could have the potential to foster creativity and flexibility which, in turn, positively impact innovativeness within a sales department.

Lastly, an environment in which employees and managers share power and the organizational culture encourages such sharing, (i.e. employees are empowered) can create an environment of openness and of people willing to share knowledge across the organization. And by doing this, indirectly and/or in synergy, it could lead to better innovation and facilitate new product selling.

The main aim of the study is to investigate the impact of internal knowledge sharing on new product selling and sales department's innovativeness as well as the impact of empowerment on internal knowledge sharing and, indirectly, on new product selling and sale innovativeness in an emerging and small market context such as Croatian. In fact, innovations have proven to be an important contributor to competitiveness and economic growth of countries (Petrariu et al., 2013). Moreover, previous studies (Švarc \& Dabić, 2019) pointed out many weaknesses in technology transfers and innovation efforts in the Republic of Croatia, whose $R \& D$ intensity (i.e. expenditure on $R \& D$ as a percentage of GDP) is only $0.97 \%$.

There is a large body of research on internal knowledge sharing, empowerment, new product selling (Wieseke et al., 2007; Sharma \& Sagar, 2017; Hohenberg \& Hahn, 2018) and on the innovation topic conducted in less developed countries (Central and Eastern Europe) and in emerging innovation systems (Petrariu et al., 2013; Stojčić et al., 2018; Stojčić, 2020). However, to the best of authors' knowledge, there is little evidence on the linkages between these constructs among salespeople in the specific context of an emerging market. Hence, the present research will fill this gap.

Sales people were chosen to be the focus of this study because of their role as boundary spanners and because of their critical importance in the last phase of the new product development process (i.e. commercialization).

Following the introduction, Section 2 provides the literature review and outlines the development of the hypotheses. Section 3 presents the methodology. Section 4 describes the empirical data and analysis, the measurement model and the structural model. Section 5 discusses the empirical results and implications. Finally, Section 6 provides the concluding remarks, limitations and directions for further research.

\section{Literature Review and Hypothesis Development}

\subsection{Internal Knowledge Sharing, New Product Selling and Sales Department's Innovativeness}

In today's ultra-competitive environment, knowledge is seen as a strategic resource whose transfer, if performed well, provides multiple benefits to companies, such as gaining competitive advantage (Hume \& Hume, 2015), strengthening entrepreneurial orientation (DeClerq, et al. , 2013), and avoiding mistakes and redundancy (Rafiq \& Ahmed, 2006). Moreover, it affects organizational performance and effectiveness (Kim \& Lee, 2006), reduces time to market (Rafiq \& Ahmed, 2006), and strengthens a company's ability to meet customer needs (Kim \& Lee, 2006).

In fact, many authors pointed out the positive effects of cross-functional integration and information sharing on achieving new product success (Arfi et al., 2019).

Furthermore, studies showed the importance of knowledge sharing in NPD processes, within the sales department and between sales and other departments (van den Berg et al., 2014) due to first-hand information and insights into customer requirements gained by sales staff. Crawford and DiBenedetto (2011) pointed out that information collected from the marketplace is an important source of information in the problem-solving process (in relation to the new product) and Matsuo (2018) saw salespeople as the central unit of interaction among different stakeholders. While Sharma and Sagar (2017) highlighted their crucial role once the product is launched, Ahearne et al. (2010) emphasized the unique position of salespeople in generating knowledge due to their regular interactions with customers. Although these interactions are under threat due to technology and social media which negatively impact the opportunities for direct interactivity between salesforce and potential customers Sharma and Sagar (2017), they were referred to as "knowledge brokers" by Verbeke and Masih (2020). The quality of such interactions is especially important in the commercialization phase. In fact, it is in 
this phase that salespeople often encounter resistance and their role as the primary source of information is to overcome resistance and facilitate the adoption of the product.

Moreover, it was suggested (Ahearne et al., 2010) that salespeople can adjust their planning and behavior based on the knowledge and insights acquired and might even be innovative (if allowed). Zhou and Li (2009) emphasized that internal knowledge exchange is more relevant for radical innovation than external knowledge acquisition if the organizational knowledge base is broad (the opposite applies if the knowledge base is deep). Tsai (2001) pointed out that better knowledge access by an organizational unit, through knowledge exchange and transfer, affects its innovation and performance. A positive relationship between knowledge sharing and performance as well as between knowledge sharing and innovation was confirmed by different studies (Wang, \& Wang, 2012; Yiu et al., 2020). Moreover, Caloghirou et al. (2004) highlighted that readiness for knowledge exchange and internal ability to recognize and exploit external knowledge improve innovative performance. Yiu et al. (2020) showed that service-oriented companies have higher innovation performance thanks to their learning from partner relationships.

Matsuo (2005) in his study highlighted the need for knowledge management systems in order to enable information sharing among salespeople and throughout the entire organization. Hohenberg and Hahn (2018) in their study pointed out that internalized new product selling motivation is crucial for performance. Borgh and Schepers (2017) highlighted the need for appropriate information sharing by a sales manager with the sales force once a new product is launched. However, knowledge management, as well as the NPD process (Helmy et al., 2019), generates costs, so it must be related to economic benefits (either revenue growth or decreased costs) or competitive advantage for the firm in order to be adopted. Van den Berg et.al. (2014) argued that in today's knowledge-based economy, knowledge development and transfer within the company act as a booster for sales performance and strongly motivate salespeople to new product selling, which in the end influences sales and overall success as well. On the other hand, Haas et al. (2007) suggested that in some cases the salesforce may be overwhelmed by knowledge sharing, which negatively affects the success of new product selling. Tang and Marinova (2020) pointed out the mixed evidence regarding the effects of knowledge sharing in NPD processes.

Mulyana et al. (2019) stated that new products and services, as well as new ways of their promotion and distribution, will represent the crucial factors for companies' success, therefore marketing innovation is seen as a vital strategic orientation. According to Hendar et al. (2018), marketing innovativeness is crucial for performance.

Studies conducted in various European countries have shown different challenges in the innovation process. Ac- cording to Švarc and Dabić (2019), the development of post-socialist economies depends on their ability to generate and exploit innovation and their ability to transfer knowledge from scientific institutions to companies. Moreover, Švarc and Dabić (2019) highlighted that in Croatia, as a typical transition country with a specific transition process (socialism to capitalism) in comparison to other EU member states, technology transfer happens slowly. Prokop and Stejskal (2017), in their study based on CIS data and conducted in Germany, Portugal, Bulgaria and Slovenia, highlighted that companies put the impetus on gaining information from various partners and documents and use it to innovate. Furthermore, Prokop and Stejskal (2017) analyzed the impact of soft knowledge infrastructure and HRST (Human Resources in Science and Technology) on the economic development of EU 28 economies in 2012 and of CEE economies between 2002 and 2012. The study showed that CEE countries were less effective than the rest of EU countries in using selected determinants of economic development. Stojčić et al. (2018), in their study conducted in Croatia, discussed different impacts of creativity in the innovation process. Hohenberg and Hahn (2018) stated that research on salesforce related factors during the commercialization phase is relatively scarce.

In the light of the above, and with the aim of broadening the knowledge of the yet insufficiently explored links between the described constructs among salespeople in the specific context of an emerging market, we hypothesize:

Hypothesis 1: Internal knowledge sharing is positively related to new product selling.

Hypothesis 2: Internal knowledge sharing is positively related to sales department's innovativeness.

\subsection{Empowerment and Internal Knowledge Sharing}

Despite the above-mentioned importance of knowledge transfer, there are a number of knowledge exchange barriers to consider in the attempt to improve internal sharing (Haas et al., 2007). Different sources (i.e. barriers), such as knowledge transferring tools, provider, receiver and context, were found threatening the cross-functional knowledge sharing during the NPD process (Hunag et al., 2008). DeClerq et al. (2013) mentioned that despite the many benefits of internal knowledge sharing, it is challenging when it occurs between different organizational functions as is the case in NPD process which involves a large number of employees (Crawford \& DiBenedetto, 2011).

Researchers noted the key role of motivation in the process of knowledge sharing (Gressgard, 2015). Moreover, the motivation for knowledge sharing derives from the individual's beliefs and from the organization's factors 
(shared values, norms, practices) that shape the individual's beliefs (Bock et al., 2005).

Furthermore, it was pointed out that knowledge sharing within organizations depends on the employee's individual behavior (Bock et al., 2005) and ability to share (Gressgard, 2015). Kim \& Lee (2006) in their study on the three elements of organizational culture (i.e. vision and goals, trust, and social networks) pointed out that social networks positively impact employee knowledge-sharing capabilities. Similarly, Mu et al. (2016) argued that besides knowledge generation, a networking ability is required too. Chen et al. (2014) in their study on knowledge sharing in virtual community showed that trust positively affects the intention to share knowledge and that high altruism makes stronger the relationship between trust and knowledge sharing. Moreover, DeClerq et al. (2013) found that trust and goal congruence (between different functions) result in more internal knowledge sharing. Hume \& Hume (2015) argued that for KM to be successful, trust, personal relevance and personnel satisfaction are needed.

Besides, authors Bock et al. (2005, p. 88) pointed out that individuals are not prone to share knowledge; in fact, sharing knowledge is more an exception than a rule within organizations. In their study on barriers in cross-functional knowledge sharing during the NPD process, Huang et al. (2008) highlighted that the use of appropriate strategies (processual and classical) can reduce these barriers and by doing this reduce the related costs. Hohenberg and Hahn (2018) stressed that new product selling bonuses can enhance the relationship between salespeople's performance predisposition and new product financial performance, but weaken the relationship between salespeople's learning predisposition and new product financial performance. Moreover, they showed that a periodic review strengthens the relationship between salespeople's learning predisposition and new product financial performance. Wang et al. (2014) pointed out that evaluation and evaluation with reward have positive impact on knowledge sharing. They also stated that knowledge sharing is influenced by the interaction between evaluation plus reward and conscientiousness, neuroticism and openness to experience. Sharma and Sagar (2017) pointed out that salespeople when selling new products often face, among others, inefficient information flow, so sales managers should effectively create and spread knowledge about the new product.

Gressgard (2015) in his study on motivational and organizational factors affecting knowledge sharing highlighted empowerment as an important intrinsic motivation factor of knowledge exchange.

Empowerment has been defined in many different ways. Conger \& Kanungo (1988, p. 473) defined empowering as a managerial strategy or technique that strengthens self-determination need or self-efficacy belief of employees and makes them feel more powerful. The employee's empowered ,state of mind“ may (Rafiq \& Ahmed, 2006) consequently lead to positive work behavior (Abbasi et al., 2020). Empowerment is also seen as a multifaceted motivational factor which can lead to altruistic behavior such as knowledge sharing (Wang et al., 2019). Kang et al. (2017) in their study showed that positive and proactive knowledge sharing behavior occurs as a consequence of knowledge management system user empowerment.

As mentioned above, empowerment is multifaceted and according to Spreitzer (1995), psychological empowerment construct merits a special critical inquiry. Spreitzer (1995) pointed out that psychological empowerment refers to the individual state of strong motivation, sense of authority and ability to perform job duties. It is in fact an active motivational orientation and it motivates people in their performance while executing different proactive tasks (Kang et al., 2017). Abbasi et al. (2020) highlighted that psychological empowerment mediates the relationship between high performance work system and knowledge sharing behavior. Al-Omari et al. (2020) in their study pointed out the positive linkages between employee empowerment and overall company performance and customer satisfaction. Grošelj et al. (2020) suggested that psychological empowerment moderates the relationship between leadership and innovative work behavior. Kang et al. (2017) considered the positive impact of psychological empowerment on different outcomes, such as effectiveness. According to Spreitzer (1995), two consequences of empowerment are effectiveness and innovative behavior. Arfi et al. (2019) examined a case in which empowering employees, among other changes in management style, facilitated knowledge exchange and firm's open innovation and performance. Furthermore, Helmy et al. (2019) pointed out that knowledge sharing mediates the relationship between the dimension of psychological empowerment (competence, impact, self-determination) and innovative work behavior. Lastly, Kang et al. (2017) stated that there has been little research investigating what motivators impact proactive knowledge sharing.

For a deeper understanding of the influence of empowerment on knowledge sharing and its indirect effects on new product selling and innovativeness of salesforce, we posit the following hypotheses:

Hypothesis 3: Empowerment is positively related to internal knowledge sharing.

H3a: Empowerment is positively related to new product selling through internal knowledge sharing

H3b: Empowerment is positively related to sales department's innovativeness through internal knowledge sharing 


\section{Methodology}

\subsection{Measurement Scales}

The data for the present research was taken from a broader study conducted among salespeople in Croatia. The questionnaire was developed using scales validated in previous research and tested by the respective authors. The measurement items used to assess Internal Knowledge were the ones developed by DeClerq et al. (2013) (7 items). In the questions related to Internal Knowledge Sharing, respondents were asked to provide their attitudes toward the relationship and collaboration between their commercial function and technically oriented functions. The Sales Department's Innovativeness level was measured using the scales developed by Matsuo (2005) (6 items), while for the assessment of the New product selling attitudes we used the van den Berg et al. (2014) scales (3 items). The measurement items used to measure Empowerment were the ones developed and tested by Spreitzer (1995) (12 items). All the scales were translated into Croatian language by an expert linguist and demographic questions were added. Respondents were asked to rate all the statements using the 7-point Likert scale (1-strongly disagree to 7-strongly agree). The data for quantitative research was collected in April and May of 2015.

\subsection{Sample}

The research on the impact of internal knowledge sharing on new product selling and sales innovation and the impact of empowerment on internal knowledge sharing was conducted on a sample of 101 key informants. The key informants were sales staff working at different levels in businesses operating in different sectors. The key informants were identified from a secondary source of information, i.e. a publication issued by a business magazine listing the top 1000 value added creators in the Republic of Croatia. The research was conducted using a highly structured questionnaire sent to organizations randomly selected from the above-mentioned list. The questionnaire was sent via email asking for it to be forwarded to salespeople at different levels within the organization. The sample structure regarding gender, age, level of education and years of sales experience of the key informants is shown in Table 1.

Table 1: The sample structure

\begin{tabular}{|c|c|}
\hline Category & (\%) \\
\hline \multicolumn{2}{|l|}{ Gender } \\
\hline M & 35.7 \\
\hline $\mathrm{F}$ & 64.3 \\
\hline \multicolumn{2}{|l|}{ Age } \\
\hline$<26$ years & 0.9 \\
\hline $26-35$ years & 19.8 \\
\hline $36-45$ years & 41.6 \\
\hline $46-55$ years & 24.8 \\
\hline$>56$ years & 12.9 \\
\hline \multicolumn{2}{|l|}{ Educational Background } \\
\hline High School Graduate & 19.8 \\
\hline Junior College Degree & 63.4 \\
\hline University Degree & 16.8 \\
\hline $\mathrm{MSc} / \mathrm{PhD}$ & 7 \\
\hline \multicolumn{2}{|l|}{ Experience in Sales } \\
\hline$<5$ years & 26.8 \\
\hline $6-10$ & 27.5 \\
\hline 11-15 & 12.7 \\
\hline$>15$ & 33 \\
\hline
\end{tabular}

Source: Authors, $\mathrm{n}=101$ 
Since the questioning method was used and all the questions in the questionnaire were answered by the same key informants (common source), there was a possibility of common method variance. Therefore, when designing the questionnaire, several procedural and statistical remedies according to Podsakoff et al. (2003) were applied to avoid the common method variance issue. The key informants were guaranteed anonymity and the instructions emphasized that there were no right or wrong answers. Furthermore, questions relating to individual constructs were neatly divided by subheadings. In terms of the statistical techniques used, the Harman's single-factor test was conducted by performing an unrotated exploratory factor analysis. According to the test performed, all indicator variables resulted in one general factor accounting for $42.46 \%$ of the total variance in all variables, which is less than $50 \%$, suggesting that common method variance would not be a major concern in this study. In addition, a confirmatory factor analysis was conducted, according to which all indicator variables were combined in one latent variable. The specified single-factor model was a poor fit to the data $(\mathrm{RMSEA}=0.20, \mathrm{CFI}=0.458 ;<0.90$, TLI $=$ $0.414 ;<0.90$ and SRMR $=0.15 ;<0.08$ ), thus further supporting a low likelihood of common method bias in this study. In the sections below, the psychometric properties of the measurement scales are tested, followed by an analysis of the structural model in relation to the proposed research hypotheses.

\section{Research Results}

\subsection{Measurement Model Analysis}

Before testing the hypotheses, we assessed the internal consistency reliability and the convergent and discrimi- nant validity of the measurement scales. Data was analyzed using the PLS-SEM method instead of the traditional CB-SEM analysis, because it offers greater flexibility regarding non-compliance under the assumption of normal variable distribution and because the PLS method gives better results in case of small sample sizes. Moreover, the PLS method is more appropriate when the research is primarily aimed at determining the predictive ability of endogenous constructs (Hair et al., 2012, Hair et al., 2014), rather than for studies whose primary focus is theory testing. Data was analyzed using SmartPLS 3.2.8. software (Ringle et al., 2015). The descriptive statistics of all items included in the analysis are reported in Table 2 . The bootstrapping method with 5,000 subsamples, as recommended by Hair et al. (2019, p. 149), was used to evaluate the measurement scales and, subsequently, to analyze the structural models. All measurement models are specified as reflective measurement models - Mode A (Hair et al., 2019 , p. 46) - based on previous research using the same measurement scales. Table 1 shows item outer loadings, CR and AVE indicators. The EMP6 (I have mastered the skills necessary for my job.), EMP7 (I have significant autonomy in determining how I do my job.), EMP8 (I can decide on my own how to go about doing my work.) and EMP9 (I have considerable opportunity for independence and freedom in how I do my job.) variables of the construct Empowerment were excluded from the analysis because their factor loadings ranged from 0.4 to 0.6 , and their exclusion led to an increase in Composite Reliability (CR) and Average Variance Extracted (AVE) above the threshold values of 0.8 and 0.5 , respectively.

Table 2: Descriptive statistics

\begin{tabular}{|l|l|l|l|l|l|l|}
\hline ITEM & $\begin{array}{l}\text { ITEM } \\
\text {-code }\end{array}$ & Mean & Median & $\begin{array}{l}\text { Standard } \\
\text { Deviation }\end{array}$ & $\begin{array}{l}\text { Excess } \\
\text { Kurtosis }\end{array}$ & Skewness \\
\hline EMPOWERMENT & & & & & & \\
\hline The work I do is very important to me. & EMP1 & 6.030 & 6.000 & 1.222 & 5.429 & -2.105 \\
\hline $\begin{array}{l}\text { My job activities are personally meaningful to } \\
\text { me. }\end{array}$ & EMP2 & 6.099 & 6.000 & 1.058 & 5.494 & -2.086 \\
\hline The work I do is meaningful to me. & EMP3 & 5.812 & 6.000 & 1.175 & 3.522 & -1.634 \\
\hline I am confident about my ability to do my job. & EMP4 & 6.287 & 6.000 & 0.825 & 15.741 & -2.842 \\
\hline $\begin{array}{l}\text { I am self-assured about my capabilities to per- } \\
\text { form my work activities. }\end{array}$ & EMP5 & 6.307 & 6.000 & 0.817 & 16.192 & -2.835 \\
\hline I have mastered the skills necessary for my job. & EMP6 & 6.109 & 6.000 & 0.866 & 10.937 & -2.255 \\
\hline $\begin{array}{l}\text { I have significant autonomy in determining how } \\
\text { I do my job. }\end{array}$ & EMP7 & 5.822 & 6.000 & 1.214 & 4.227 & -1.809 \\
\hline
\end{tabular}


Table 2: Descriptive statistics (continues)

\begin{tabular}{|c|c|c|c|c|c|c|}
\hline $\begin{array}{l}\text { I can decide on my own how to go about doing } \\
\text { my work. }\end{array}$ & EMP8 & 5.337 & 6.000 & 1.307 & 1.333 & -1.162 \\
\hline $\begin{array}{l}\text { I have considerable opportunity for indepen- } \\
\text { dence and freedom in how I do my job. }\end{array}$ & EMP9 & 5.149 & 5.000 & 1.360 & 1.068 & -1.065 \\
\hline $\begin{array}{l}\text { My impact on what happens in my department } \\
\text { is large. }\end{array}$ & EMP10 & 4.832 & 5.000 & 1.548 & -0.194 & -0.753 \\
\hline $\begin{array}{l}\text { I have a great deal of control over what happens } \\
\text { in my department. }\end{array}$ & EMP11 & 5.317 & 6.000 & 1.495 & 1.275 & -1.298 \\
\hline $\begin{array}{l}\text { I have significant influence on what happens in } \\
\text { my department. }\end{array}$ & EMP12 & 4.842 & 5.000 & 1.565 & 0.133 & -0.881 \\
\hline \multicolumn{7}{|l|}{ SALES DEPARTMENT'S INNOVATIVENESS } \\
\hline $\begin{array}{l}\text { Our ability to function creatively is respected by } \\
\text { the leadership. }\end{array}$ & $\begin{array}{l}\text { SA L I N N - } \\
\text { OV1 }\end{array}$ & 4.980 & 6.000 & 1.528 & 0.659 & -1.165 \\
\hline Creativity is encouraged here. & $\begin{array}{l}\text { SALIN N- } \\
\text { OV2 }\end{array}$ & 4.614 & 5.000 & 1.688 & -0.408 & -0.826 \\
\hline $\begin{array}{l}\text { Around here, people are allowed to try to solve } \\
\text { the same problems in different ways. }\end{array}$ & $\begin{array}{l}\text { SALIN N - } \\
\text { OV3 }\end{array}$ & 4.762 & 5.000 & 1.517 & 0.217 & -1.023 \\
\hline $\begin{array}{l}\text { This organization can be described as flexible } \\
\text { and continually adapting to change. }\end{array}$ & $\begin{array}{l}\text { SALIN N- } \\
\text { OV4 }\end{array}$ & 4.723 & 5.000 & 1.672 & -0.554 & -0.712 \\
\hline $\begin{array}{l}\text { This organization is open and responsive to } \\
\text { change. }\end{array}$ & $\begin{array}{l}\text { SA L I N N - } \\
\text { OV5 }\end{array}$ & 4.733 & 5.000 & 1.515 & -0.487 & -0.576 \\
\hline The reward system here encourages innovation. & $\begin{array}{l}\text { SALIN N- } \\
\text { OV6 }\end{array}$ & 4.119 & 4.000 & 1.831 & -1.331 & -0.227 \\
\hline \multicolumn{7}{|l|}{ NEW PRODUCT SELLING } \\
\hline $\begin{array}{l}\text { I like to present my customers with our most in- } \\
\text { novative products. }\end{array}$ & NPS1 & 5.881 & 6.000 & 1.065 & 3.769 & -1.506 \\
\hline $\begin{array}{l}\text { I like selling products that need me to explain in } \\
\text { great detail just what is new and exciting about } \\
\text { them. }\end{array}$ & NPS2 & 5.752 & 6.000 & 1.121 & 1.877 & -1.338 \\
\hline $\begin{array}{l}\text { I like to visit new accounts where I have to pres- } \\
\text { ent what my company is selling. }\end{array}$ & NPS3 & 5.624 & 6.000 & 1.319 & 1.369 & -1.193 \\
\hline \multicolumn{7}{|l|}{ INTERNAL KNOWLEDGE SHARING } \\
\hline $\begin{array}{l}\text { There is close interaction and collaboration be- } \\
\text { tween people in the two functions. }\end{array}$ & IKS1 & 5.129 & 5.000 & 1.355 & 0.870 & -1.014 \\
\hline $\begin{array}{l}\text { There is open communication between people in } \\
\text { the two functions. }\end{array}$ & IKS2 & 5.129 & 6.000 & 1.433 & 0.855 & -1.153 \\
\hline $\begin{array}{l}\text { There is high level of knowledge sharing be- } \\
\text { tween people in the two functions. }\end{array}$ & IKS3 & 4.822 & 5.000 & 1.485 & -0.031 & -0.829 \\
\hline $\begin{array}{l}\text { People in the two functions have great dialogues } \\
\text { with each other. }\end{array}$ & IKS4 & 4.941 & 5.000 & 1.326 & 0.912 & -0.949 \\
\hline $\begin{array}{l}\text { People in the two functions regularly communi- } \\
\text { cate with each other. }\end{array}$ & IKS5 & 5.129 & 5.000 & 1.376 & 1.343 & -1.161 \\
\hline $\begin{array}{l}\text { People in the two functions provide each other } \\
\text { with a lot of feedback. }\end{array}$ & IKS6 & 4.792 & 5.000 & 1.430 & 0.368 & -0.801 \\
\hline $\begin{array}{l}\text { There is a lot of two-way communication be- } \\
\text { tween people in the two functions. }\end{array}$ & IKS7 & 4.891 & 5.000 & 1.421 & 0.543 & -1.004 \\
\hline
\end{tabular}

Source: Authors' own calculation 
As shown in Table 3 below, all investigated constructs had satisfactory Cronbach's alpha, Composite Reliability (CR) and Average Variance Extracted (AVE) values. Cronbach's alpha and CR coefficients ranged between 0.8 and 0.96 and they all exceeded the recommended cut-off of 0.8. Besides, all of the AVE scores were above 0.5, ranging from 0.53 to 0.80 . According to the below data, all the constructs showed an acceptable level of internal consistency reliability and convergent validity.
The cross-loading analysis as well as the Fornell-Larcker criterion (1981) and the Heterotrait-Monotrait (HTMT) ratio confidence intervals were used to assess the discriminant validity. The results of the cross-loading analysis showed that the outer loadings were high on their respective constructs, but low on all other constructs. The Fornell-Larcker criterion and the HTMT ratio are shown in Table 4.

Table 3: Internal consistency reliability and convergent validity

\begin{tabular}{|c|c|c|c|c|c|c|}
\hline Construct/Item & $\begin{array}{c}\text { Original } \\
\text { Sample (0) }\end{array}$ & $\begin{array}{l}\text { Standard } \\
\text { Deviation } \\
\text { (STDEV) }\end{array}$ & $\begin{array}{c}\text { T Statistics (|O/ } \\
\text { STDEV|) }\end{array}$ & $\begin{array}{c}\text { Cronbach's } \\
\text { Alpha }\end{array}$ & $\begin{array}{l}\text { Composite } \\
\text { Reliability } \\
\text { (CR) }\end{array}$ & $\begin{array}{c}\text { Average Variance } \\
\text { Extracted } \\
\text { (AVE) }\end{array}$ \\
\hline \multicolumn{7}{|l|}{$\begin{array}{c}\text { Internal Knowledge } \\
\text { Sharing }\end{array}$} \\
\hline IKS1 <- IKS & $0.895^{*}$ & 0.024 & 37.033 & \multirow{7}{*}{0.95} & \multirow{7}{*}{0.96} & \multirow{7}{*}{0.80} \\
\hline IKS2 <- IKS & $0.927^{*}$ & 0.016 & 58.983 & & & \\
\hline IKS3 <- IKS & $0.889 *$ & 0.032 & 28.031 & & & \\
\hline IKS4 <- IKS & $0.898^{*}$ & 0.029 & 30.504 & & & \\
\hline IKS5 <- IKS & $0.887^{*}$ & 0.031 & 28.771 & & & \\
\hline IKS6 <- IKS & $0.888^{*}$ & 0.030 & 29.941 & & & \\
\hline IKS7 <- IKS & $0.874^{*}$ & 0.038 & 23.089 & & & \\
\hline \multicolumn{7}{|l|}{ New Product Selling } \\
\hline NPS1 <- NPS & $0.896^{*}$ & 0.056 & 15.977 & \multirow{3}{*}{0.87} & \multirow{3}{*}{0.92} & \multirow{3}{*}{0.79} \\
\hline NPS2 <- NPS & $0.899 *$ & 0.061 & 14.675 & & & \\
\hline NPS3 <- NPS & $0.879 *$ & 0.069 & 12.643 & & & \\
\hline \multicolumn{7}{|l|}{$\begin{array}{l}\text { Sales Department's } \\
\text { Innovativeness }\end{array}$} \\
\hline $\begin{array}{c}\text { SALINNOV1 <- SALIN- } \\
\text { NOV }\end{array}$ & $0.894^{*}$ & 0.023 & 38.698 & \multirow{6}{*}{0.92} & \multirow{6}{*}{0.94} & \multirow{6}{*}{0.73} \\
\hline $\begin{array}{c}\text { SALINNOV2 <- SALIN- } \\
\text { NOV }\end{array}$ & $0.902 *$ & 0.022 & 40.177 & & & \\
\hline $\begin{array}{c}\text { SALINNOV3 <- SALIN- } \\
\text { NOV }\end{array}$ & $0.822 *$ & 0.046 & 17.790 & & & \\
\hline $\begin{array}{c}\text { SALINNOV4 <- SALIN- } \\
\text { NOV }\end{array}$ & $0.883^{*}$ & 0.031 & 28.491 & & & \\
\hline $\begin{array}{c}\text { SALINNOV5 <- SALIN- } \\
\text { NOV }\end{array}$ & $0.884^{*}$ & 0.030 & 29.910 & & & \\
\hline $\begin{array}{c}\text { SALINNOV6 <- SALIN- } \\
\text { NOV }\end{array}$ & $0.736^{*}$ & 0.060 & 12.222 & & & \\
\hline
\end{tabular}


Table 3: Internal consistency reliability and convergent validity (continues)

\begin{tabular}{|c|c|c|c|c|c|c|}
\hline Empowerment & & & & & & \\
\hline EMP1 <- EMP & $0.786 *$ & 0.062 & 12.681 & \multirow{8}{*}{0.87} & \multirow{8}{*}{0.89} & \multirow{8}{*}{0.53} \\
\hline EMP2 <- EMP & $0.752 *$ & 0.086 & 8.785 & & & \\
\hline EMP3 <- EMP & $0.870 *$ & 0.047 & 18.597 & & & \\
\hline EMP4 <- EMP & $0.614^{*}$ & 0.194 & 3.170 & & & \\
\hline EMP5 <- EMP & $0.600 *$ & 0.200 & 3.001 & & & \\
\hline EMP10 <- EMP & $0.693^{*}$ & 0.104 & 6.634 & & & \\
\hline EMP11 <- EMP & $0.750 *$ & 0.079 & 9.526 & & & \\
\hline EMP12 <- EMP & $0.697 *$ & 0.109 & 6.411 & & & \\
\hline
\end{tabular}

$* \mathrm{p}<0.05$

Source: Authors' own calculation

Table 4: Fornell-Larcker criterion and HTMT ratio*

\begin{tabular}{|c|c|c|c|c|c|c|c|}
\hline & \multicolumn{4}{|l|}{ Fornell-Larcker criterion $* *$} & \multicolumn{3}{l|}{ HTMT ratio (95\% bias corrected interval) } \\
\hline & EMP & IKS & NPS & SALINNOV & EMP & IKS & NPS \\
\hline EMP & $\mathbf{0 , 7 2 5}$ & & & & & & \\
\hline IKS & 0.555 & $\mathbf{0 . 8 9 4}$ & & & $\begin{array}{c}0.569(0.376- \\
0.737)\end{array}$ & \\
\hline NPS & 0.514 & 0.343 & $\mathbf{0 . 8 9 1}$ & & $\begin{array}{c}0.579(0.424- \\
0.724)\end{array}$ & $\begin{array}{c}0.364(0.139- \\
0.603)\end{array}$ & \\
\hline SALINNOV & 0.648 & 0.633 & 0.396 & $\mathbf{0 . 8 5 6}$ & $\begin{array}{c}0.695(0.551- \\
0.792)\end{array}$ & $\begin{array}{c}0.664(0.518- \\
0.781)\end{array}$ & $\begin{array}{c}0.430(0.251- \\
0.593)\end{array}$ \\
\hline
\end{tabular}

*EMP - Empowerment, IKS - Internal Knowledge Sharing, NPS - New Product Selling, SALINNOV - Sales Department's Innovativeness ** Construct correlation matrix with the square root of the AVE on the diagonal in bold

Source: Authors' own calculation

According to the data presented in Table 4, the Fornell-Larcker criterion was met and the square root of the AVE for each construct was greater than the correlation between the construct and all other constructs. The HTMT values between constructs were all below 0.85 , indicating that none of the HTMT confidence interval bias-corrected values included the value of 1 . All the above data suggest satisfactory discriminant validity of the measurement scales. The next section provides an analysis of the structural model.

\subsection{Structural Model Analysis}

This research is based on the assumption of a positive impact of Empowerment through Internal Knowledge Sharing on New Product Development and Sales Innovation (Figure 1).

A VIF test was used to check for multicollinearity among endogenous constructs. The VIF for each pair of endogenous constructs was below the threshold of 5, so it could be concluded that multicollinearity among endogenous constructs would not be a major concern in this study. The results of the structural model analysis are illustrated in Table 5.

The results of the structural model analysis supported all the proposed hypotheses. Direct effects were analyzed within the framework of the model. In this respect, Empowerment (EMP) had a statistically significant positive direct effect on Internal Knowledge Sharing (IKS) (H1: $\beta=0.555 ; \mathrm{t}=7.192 ; \mathrm{p}<0.05)$, which in return had a positive direct effect on New Product Selling (NPS) (H3: $\beta=0.343$; $\mathrm{t}=3.106 ; \mathrm{p}<0.05)$ and Sales Department's Innovativeness (SALINNOV) $(\mathrm{H} 4: \beta=0.633 ; \mathrm{t}=10.209 ; \mathrm{p}<0.05)$. Likewise, two statistically significant positive indirect effects were found, namely Empowerment through Internal Knowledge Sharing positively affects Sales Department's Innovativeness ( $\beta$ indirect $=0.351 ; \mathrm{t}=5.095, \mathrm{p}<0.05$ ) and New Product Selling ( $\beta$ indirect $=0.351 ; \mathrm{t}=5.095, \mathrm{p}<0.05$ ). The effect size of the construct Empowerment was moderate, it explained $31 \%$ of Internal Knowledge Sharing construct variance 


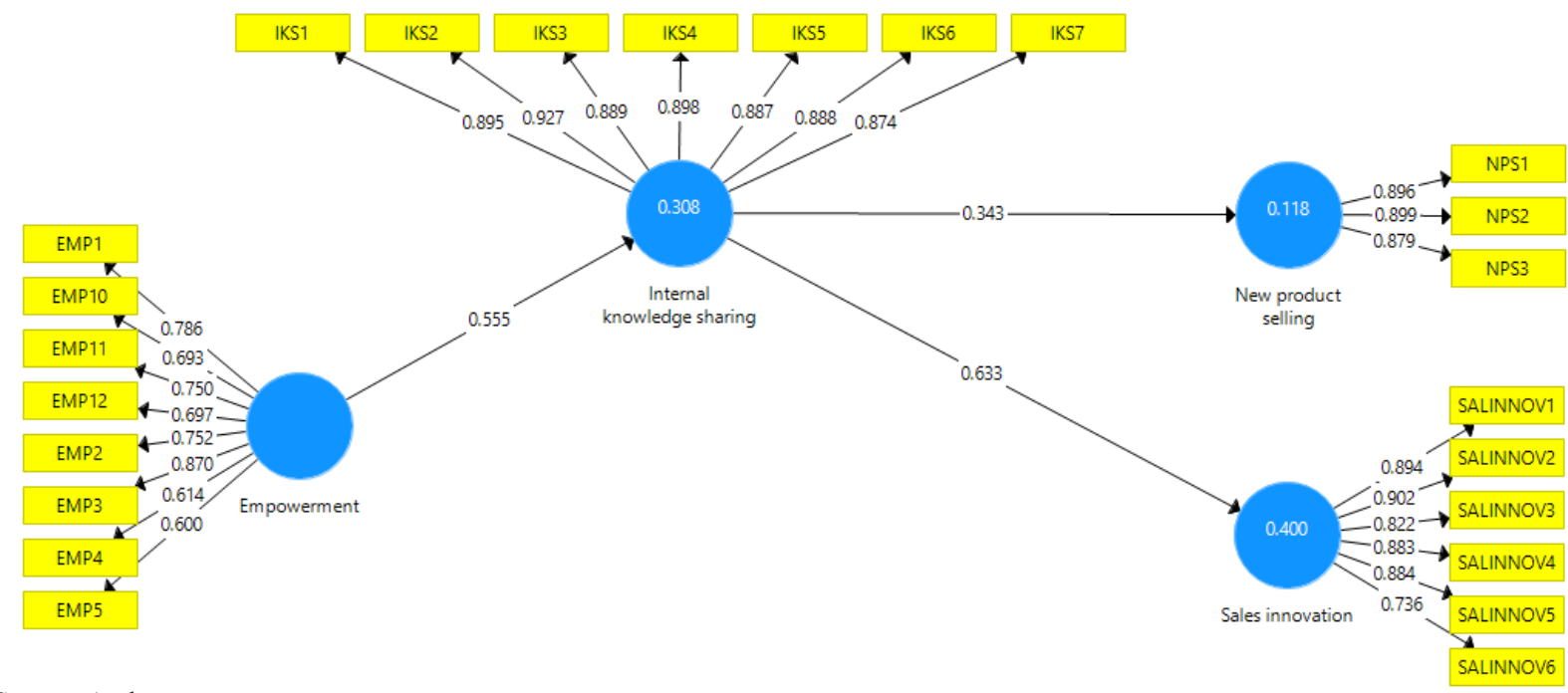

Source: Authors

Figure 1: Structural model

Table 5: Direct and indirect effects

\begin{tabular}{|c|c|c|c|c|c|c|c|}
\hline Hypothesis & $\begin{array}{c}\text { Original } \\
\text { Sample (0) }\end{array}$ & $\begin{array}{c}\text { Standard Devi- } \\
\text { ation (STDEV) }\end{array}$ & $\begin{array}{l}\text { T Statistics } \\
\text { (|O/STDEV|) }\end{array}$ & $\begin{array}{l}95 \% \text { bias cor- } \\
\text { rected interval }\end{array}$ & $\mathbf{R}^{2}$ & $f^{2}$ & $\begin{array}{l}\text { Hypothesis } \\
\text { Acceptance }\end{array}$ \\
\hline & \multicolumn{3}{|c|}{ Direct and Total Effects } & & & & \\
\hline $\begin{array}{l}\text { H1: Internal Knowl- } \\
\text { edge Sharing } \\
\text {->New Product } \\
\text { Selling }\end{array}$ & $0.343 *$ & 0.110 & 3.106 & $0.124-0.539$ & 0.12 & 0.13 & Accepted \\
\hline $\begin{array}{l}\text { H2: Internal Knowl- } \\
\text { edge Sharing } \\
\text {->Sales Depart- } \\
\text { ment's Innovative- } \\
\text { ness }\end{array}$ & $0.633^{*}$ & 0.062 & 10.209 & $0.488-0.745$ & 0.40 & 0.67 & Accepted \\
\hline \multirow[t]{2}{*}{$\begin{array}{l}\text { H3: Empowerment } \\
\text {->Internal Knowl- } \\
\text { edge Sharing }\end{array}$} & $0.555^{*}$ & 0.077 & 7.192 & $0.373-0.687$ & 0.31 & 0.44 & Accepted \\
\hline & \multicolumn{3}{|c|}{ Indirect Effects } & & & & \\
\hline $\begin{array}{c}\text { H3a: } \\
\text { Empowerment -> } \\
\text { Internal Knowledge } \\
\text { Sharing -> Sales } \\
\text { Department's Inno- } \\
\text { vativeness }\end{array}$ & $0.351 *$ & 0.069 & 5.095 & $0.208-0.475$ & & & Accepted \\
\hline $\begin{array}{l}\text { H3b:Empowerment } \\
\text {-> Internal Knowl- } \\
\text { edge Sharing - New } \\
\text { Product Selling }\end{array}$ & $0.190 *$ & 0.083 & 2.279 & $0.049-0.356$ & & & Accepted \\
\hline
\end{tabular}

$* \mathrm{p}<0.05$

Source: Authors' own calculation 
$(\mathrm{R} 2=0.31)$, while Internal Knowledge Sharing explained $12 \%$ of variance in the endogenous construct of New Product Selling $(\mathrm{R} 2=0.12)$ and its effect size was moderate i.e. explained $40 \%$ of variance in Sales Innovation $(\mathrm{R} 2=0.40)$. In terms of the effect size, according to Cohen (1988) there was a large effect size ( $\mathrm{f} 2=0.44$ ) of the construct of Empowerment on Internal Knowledge Sharing and a medium (f2=0.13) effect size of Internal Knowledge Sharing on New Product Selling, whereas the effect size of the latter construct on Sales Innovation was strong ( $\mathrm{f} 2=0.67$ ). The predictive relevance of the model was examined using the blindfolding procedure. All Q2 values were greater than 0 , thus providing support for the model's predictive relevance in respect of all endogenous constructs. The next section discusses in more detail the theoretical and practical implications of the research findings.

\section{Discussion and Implications}

The present study has revealed that internal knowledge sharing is positively linked with new product selling and sales department's innovativeness. The research results are in line with Tsai (2001), Wang and Wang, (2012) and Yiu et al. (2020); namely, they argued about the impact of knowledge sharing on innovation and performance. These links were confirmed within the sales department (i.e. among salespeople). Our research can be added to Prokop and Stejskal's study (2017), as it shows that sharing of the knowledge acquired in the marketplace between sales and technical department in the specific context of Croatian economy can bring innovation (in sales) and enhance new product selling. Moreover, the proven positive effect of empowerment on internal knowledge sharing and, indirectly, on new product selling and sales innovativeness is in line with the research conducted by Kang et al. (2017), who pointed out the positive impact of empowerment on proactive tasks, and with van den Berg et al. (2014) study focusing on the role of knowledge transfer on performance and new product selling.

A number of practical implications arise from this study. As stated above, regular knowledge sharing improves the final stage of the NPD process and positively affects the innovativeness of sales department. Based on this evidence, top management and sales management should jointly adopt appropriate internal knowledge practices, develop an internal knowledge sharing system and undertake different activities in order to facilitate and encourage knowledge sharing, such as developing an appropriate organizational culture, rewarding knowledge sharing, or conducting internal marketing activities. Salespeople get first-hand feedback from customers, so it is important to enable and encourage sharing of such valuable information, especially with the technical department. Shared information may allow faster response to customer needs. Managers should empower knowledge system users and encourage (i.e. empower) knowledge exchange between employees while selling new product, with the aim of fostering creativity and flexibility among them and bettering the process.

However, this striving can be a challenge as well; there is a number of different obstacles to overcome in the knowledge sharing enhancement efforts.

Attitudes, beliefs and motivation are important drivers for knowledge sharing and according to the present study, empowered people are more prone to share knowledge. Accordingly, sales managers should allow discretion which can be formalized (documents, procedures) or implied (organizational culture) and encouraged through training and personal (i.e. managers') example, meaning that by doing this they'll impact employee's knowledge-sharing behavior. Finally, empowerment will lead to better product selling and more creativity and flexibility among salespeople. These outcomes will positively impact the company's overall performance and contribute to the national economy. Therefore, salespeople should be empowered, but according to past studies (Sharma \& Sagar, 2017; Homburg \& Hahn, 2018), effective knowledge transfer from sales managers to their sales teams and an appropriate financial policy framework (i.e. bonuses) should be in place as well.

The present study contributes to the body of knowledge with new insights on the topic from the sales department's perspective. In fact, while previous research has shown the effects of empowerment and internal knowledge sharing in different settings and the effects of these factors with different outcomes (Al-Omari et al., 2020; Yiu et al., 2020), the links between empowerment and internal knowledge sharing as well as between these constructs and new product selling and sales innovativeness have not been investigated in salespeople in a specific emerging market context. Because of the specific role of salespeople in the commercialization phase and the need for innovation within the sales department itself, many companies struggle with their sales force. Sales personnel as boundary spanners collect a large amount of information and play a crucial role in product commercialization. With the aim of addressing the above gap, we conducted the current research. This study's findings corroborate previous research, but also contribute to the literature by highlighting the relevant links in the specific sales and economic context.

\section{Conclusions, Limitations and Future Research}

Innovations are crucial both for companies and for national economies. Companies should innovate due to intense competition and customer expectancy and governments should innovate for the sake of their country's economic growth. But there are a number of challenges on this path and all the steps and specificities should be 
examined in order to better this process. Our research dealt with the last stage of the process - new product selling and the innovativeness of people who sell the products. In fact, in this process, employees, especially those who are in direct contact with potential customers, play an important role. Their innovativeness and efforts can be particularly valuable when the product faces the market for the first time (i.e. in the commercialization phase). Salespeople's role has already been recognized as important, but at the same time a number of issues faced by companies dealing with salesforce selling new product have been pointed out. Despite the above-mentioned importance of innovation, different challenges have been identified in the context of an emerging market economy. Lastly, because of a number of similar products on the market, creativity and flexibility are important for salespeople and they should as well be boosted. Based on the study's evidence, this outcome can be influenced by knowledge sharing and empowerment, while knowledge sharing can be affected by adequate empowerment of salespeople.

The present findings may help companies in their striving to avoid losses and launch products more successfully. Moreover, the addressed process characterized by high investment and failure rates could be improved by the joint efforts of practitioners and scientists. The present study has some limitations that may serve as the basis for future research. A larger study sample with an appropriate structure of businesses in terms of size and sector would provide more valid and more reliable research findings and a better generalization of the results. Moreover, since in the larger portion of the sample only one salesperson per company was surveyed due to time and cost limitations, involving more employees at different levels in the sales team of an organization, i.e. the use of the triangulation method, would yield more accurate results.

Furthermore, due to the sample size, the authors did not check the unobserved heterogeneity that may reduce the accuracy of the conclusions of the study in case of different segments - groups of key informants.

The study was conducted on cross-sectional data i.e. it lacks an analysis of the observed phenomena from a dynamic perspective, which should be covered by future research in order to obtain a better insight into the causal relationships among the investigated constructs.

The knowledge gained within this study could be broadened in future research by including some moderating variables between the Empowerment and the Internal Knowledge Sharing constructs, such as organizational culture of the company, job satisfaction, personality traits of salespeople, selling style, sales staff motivation, job burnout syndrome.

In addition, it would be useful if future research encompassed the types of information shared between managers, salesforce and other employees, and the impact of such information on sales process innovation and new product development.

\section{Acknowledgment}

"This paper is a result of the scientific project The Use and Perceptions of Holistic Marketing in Croatia supported by the Faculty of Economics and Tourism "Dr. Mijo Mirković", Juraj Dobrila University of Pula. Any opinions, findings, and conclusions or recommendations expressed in this paper are those of the author(s) and do not necessarily reflect the views of the Faculty of Economics and Tourism "Dr. Mijo Mirković" Pula."

\section{Literature}

Abbasi, S.G., Shabbir, M.S., Abbas, M, Tahir, M.S. (2020). HPWS and knowledge sharing behavior: The role of psychological empowerment and organizational identification in public sector banks. Journal Public Affairs, Article e2512. https://doi.org/10.1002/pa.2512

Ahearne, M., Rapp, A., Hughes, D. E. \& Jindal, R. (2010). Managing Sales Force Product Perceptions and Control Systems in the Success of New Product Introductions. Journal of Marketing Research, 47(4), 764-776. https://doi.org/10.1509\%2Fjmkr.47.4.764

Ahmed, P. K. \& Rafiq, M. (2006). Internal Marketing: Tools and Concepts for Customer-Focused Management. Oxford: Butterworth-Heineman

Al-Omari,Z.,S., Alomari K., A.,A., \& Aljawarneh N.,M., (2020). The role of empowerment in improving internal process, customer satisfaction, learning and growth. Management Science Letters, 10, 841-848. http://doi.org/10.5267/j.msl.2019.10.013

Arfi W. B., Enstrom R., Sahut J.M., \& Hikkerova L. (2019). The significance of knowledge sharing platforms for open innovation success, Journal of Organizational Change Management, 32(5), 496-516. http:// doi.org/10.1108/JOCM-09-2018-0256

Bock G., Zmud R., Kim Y., \& Lee J. (2005). Behavioral Intention Formation in Knowledge Sharing: Examining the Roles of Extrinsic Motivators, Social-Psychological Forces, and Organizational Climate. MIS Quarterly, 29 (1), 87-111. http://doi.org/10.2307/25148669

Borghl M., \& Schepers J., (2017), Are conservative approaches to new product selling a blessing in disguise? The Journal of the Academy Marketing Science, 46, 857-878. http://doi.org/10.1007/s11747-017-0521-1

Caloghirou Y., Kastelli I., \& Tsakanikas A. (2004). Internal capabilities and external knowledge sources: complements or substitutes for innovative performance? Technovation, 24, 29-39. http://doi.org/10.1016/S01664972(02)00051-2

Crawford, M., \& DiBenedetto, A. (2011). New Product Management. (10th ed.). New York, NY: McGraw-Hill Irwin

Chen H., Fan H. \& Tsai C. (2014). The Role of Commu- 
nity Trust and Altruism in Knowledge Sharing: An Investigation of a Virtual Community of Teacher Professionals. Journal of Educational Technology \& Society, 17(3), 168-179.

Conger J.A. \& Kanungo R.N. (1988). The Empowerment Process: Integrating Theory and Practice. The Academy of Management Review, 13 (3), 471-482. https:// doi.org/10.5465/amr.1988.4306983

Grošelj, M., Černe M., Penger S. \& Grah B. (2020). Authentic and transformational leadership and innovative work behaviour: the moderating role of psychological empowerment. European Journal of Innovation Management, 1460 - 1060. https://doi.org/10.1108/EJIM10-2019-0294

De Clercq D., Thongpapanl N. \& Dimov D. (2013). Organizational Social Capital, Formalization, and Internal Knowledge Sharing in Entrepreneurial Orientation Formation, Entrepreneurship Theory and Practice, 37(3), 505-537. https://doi.org/10.1111/etap.12021

Fornell, C. \& Larcker, D.F., (1981). Evaluating structural equation models with unobservable variables and measurement error. Journal of Marketing Research, 18(1), 39-50. https://doi.org/10.2307/3151312

Gressgård L. J. (2015). Antecedents of Knowledge Exchange Systems Usage: Motivational and Work Environment Factors. Knowledge and Process Management. 22(2), 112-125. https://doi.org/10.1002/kpm.1471

Hair, J.F., Ringle, M. C. \& Sarstedt, M. (2012). Partial Least Squares: The better approach to structural equation modeling? Long Range Planning, 45(5-6), 312319. http://dx.doi.org/10.1016/j.lrp.2013.01.001

Hair, J.F., Hult, M. T., Ringle, M. C. \& Sarstedt, M. (2014). A Primer on Partial Least Squares Structural Equation Modeling. CA: SAGE Publications Ltd.

Hair, J.F., Sarstedt, M., Risher, J.J. \& Ringle, M. C. (2019). When to use and how to report the results of PLS-SEM. European Business Review, 31 (1), 2-24

Hass M. R. \& Morten T. Hansen (2007) Different Knowledge, Different Benefits: Toward a Productivity Perspective on Knowledge Sharing in Organizations. Strategic Management Journal, 28 (11), 1133-1153. https://doi.org/10.1002/smj.631

Healy, M., Cleary, P. \& Walsh, E. (2018). Innovativeness and accounting practices: an empirical investigation. Qualitative Research in Accounting \& Management, 1176-6093 https://doi.org/10.1108/QRAM-06-20170047

Helmy I., Adawiyah W.,R. \& Banani A. (2019). Linking Psychological Empowerment, Knowledge Sharing, and Employees. Innovative Behavior in Indonesian SMEs. The Journal of Behavioral Science. 14(2), 6679. Retrieved from https://so06.tci-thaijo.org/index. php/IJBS/article/view/172180

Homburg C., Hohenberg S. \& Hahn A. (2019). Steering the Sales Force for New Product Selling: Why Is It Dif- ferent, and How Can Firms Motivate Different Sales Reps?, Journal of Product Innovation management, 36(3), 282-304. https://doi.org/10.1111/jpim. 12476

Huang Ch-M., Chang J. \& Henderson S. (2008) Knowledge Transfer Barriers Between Research and Development and Marketing Groups Within Taiwanese Small- and Medium-Sized Enterprise High-Technology New Product Development Teams. Human Factors and Ergonomics in Manufacturing, 18 (6), 621-657. https://doi.org/10.1002/hfm.20130

Hume C. \& Hume M. (2015). The Critical Role of Internal Marketing in Knowledge Management in Not-forProfit Organizations. Journal of Nonprofit \& Public Sector Marketing, 27, 23-47. https://doi.org/10.1080/ 10495142.2014 .934567

Kang Y.,J., Lee J., Y. \& Kim H., W. (2017). A psychological empowerment approach to online knowledge sharing. Computers in Human Behavior 74, 175 - 18. http://dx.doi.org/10.1016/j.chb.2017.04.039

Kim S. \& Lee H. (2006). The Impact of Organizational Context and Information Technology on Employee Knowledge-Sharing Capabilities. Public Administration Review, 66(3), 370-385. https://doi.org/10.1111/ j.1540-6210.2006.00595.x

Matsuo M., (2018). Sales management: Learning and innovationin Japan, Journal of Marketing Channels, 25(4), 241-244, https://doi.org/10.1080/104666 9X.2019.1658014

Matsuo, M. (2005). The Influence of Sales Management Control on Innovativeness of Sales Departments. The Journal of Personal Selling and Sales Management, 29(4), 321-333. https://doi.org/10.2753/PSS08853134290402

Mu J., Thomas E., Peng G. \& Di Benedetto A. (2017). Strategic orientation and new product development performance:The role of networking capability and networking ability, Industrial Marketing Management, 64(July), 187-201. http://dx.doi.org/10.1016/j.indmarman.2016.09.007

Mulyana M., Hendar H.,Zulfa M. \& Ratnawati A. (2020). Marketing Innovativeness on Marketing Performance: Role of Religio-Centric Relational Marketing Strategy. Journal of Relationship Marketing, 19(1), 52-74. https://doi.org/10.1080/15332667.2019.1664869

Noorderhaven N. \& Harzing A. (2009). Knowledge-Sharing and Social Interaction within MNEs. Journal of International Business Studies, 40(5), 719-741. Retrieved from http://www.jstor.org/stable/40262806

Podsakoff P.M., MacKenzie S.B, Lee J-Y. \& Podsakoff N. (2003). Common Method Biases in Behavioral Research: A Critical Review of the Literature and Recommended Remedies. Journal of Applied Psychology, 88(5), 879-903 https://doi.org/10.1037/00219010.88.5.87934

Prokop V. \& Stejskal J. (2017). The Influence of Infor- 
mation Sharing and Collaboration on the Extent of Innovation activities. International Conference on Knowledge Engineering and Applications. https://doi. org/10.1109/ICKEA.2017.8169907

Petrariu I., R., Bumbac R. \& Ciobanu R. (2013). Innovation: a path to competitiveness and economic growth. The case of CEE countries. Theoretical and Applied Economics. 5(582), 15-26.

Ringle, C. M., Wende, S. \& Becker, J.-M. (2015). "SmartPLS 3." Boenningstedt: SmartPLS GmbH, http://www. smartpls.com. Rossiter, 2002.

Sharma A. \& Sagar, M. (2018). New product selling challenges (key insights in the ICT sector). Journal of Indian Business Research, 10(3) 291-319. https://doi. org/10.1108/JIBR-11-2017-0216

Spreitzer M., G. (1995). Psychological Empowerment In The workplace: Dimensions, Measurement And Validation. The Academy of Management Journal, 38(5), 42-1465. https://doi.org/10.2307/256865

Stojčić N. (2020). Collaborative innovation in emerging innovation systems: Evidence from Central and Eastern Europe. The Journal of Technology Transfer, 46, 531-562. https://doi.org/10.1007/s10961-020-09792-8

Stojčić N., Hashi I. \& Aralica Z. (2018). Creativity, innovations and firm performance in an emerging transition economy. Ekonomski Pregled, 69(3), 203-228

Švarc J. \& Dabić M. (2019). The Croatian path from socialism to European membership through the lens of technology transfer policies., The Journal of Technology Transfer, 44, 1476-1504. https://doi.org/10.1007/ s10961-019-09732-1

Song M. \& Parry M. (1997). The Determinants of Japanese New Product Successes. Journal of Marketing Research, 34 (1), 64-76. https://doi.org/10.2307/3152065

Tang Y.E \& Marinova D. (2020). When less is more: the downside of customer knowledge sharing in new product development teams, Journal of the Academy of Marketing Science, 48, 288-307. https://doi. org/10.1007/s11747-019-00646-w

Tsai W. (2001). Knowledge Transfer in Intraorganizational Networks: Effects of Network Position and Absorptive Capacity on Business Unit Innovation and Performance, The Academy of Management Journal, 44(5), 996-1004. https://doi.org/10.2307/3069443

Van den Berg, W. E., Verbeke, W., Bagozzi, R. P., Worm, L., de Jong, A. \& Nijssen, E. (2014). Salespersons as Internal Knowledge Brokers and New Products Selling: Discovering the Link to Genetic Makeup. The Journal of Product Innovation Management, 31(4), 695-709. https://doi.org/10.1111/jpim.12156

Verbeke W.J.M.I \& Masih J. (2020). Evolutionary-shaped goal orientation in Homosapiens: how life sciences contribute to a better understanding of salespeople as knowledge brokers, Journal of Personal Selling\& Sales Management, 40(1), 43-56, https://doi.org/10.10
80/08853134.2019.1654389

Wang S., Noe R. A. \& Wang Z. (2014). Motivating Knowledge Sharing in Knowledge Management Systems: A Quasi-Field Experiment. Journal of Management, 40(4), 978-1009. https://doi. org/10.1177/0149206311412192

Wang Z. \& Wang N. (2012). Knowledge sharing, innovation and firm performance. Expert Systems with Applications, 39(10), 8908 -8899. https://doi.org/10.1016/j. eswa.2012.02.017

Wieseke J., Homburg C. \& Lee N. (2008). Understanding the adoption of new brands through sales people: a multilevel framework. Journal of the Academy of Marketing Science, 36(2), 278 - 291. https://doi. org/10.1007/s11747-007-0055-Z

Yiu H. L., Ngai E.W.T. \& Lei C. F. (2020). Impact of Service-Dominant Orientation on the Innovation Performance of Technology Firms: Roles of Knowledge Sharing and Relationship Learning. A Journal of Decision Sciences Institute, 51(3), 620 - 653. https://doi. org/10.1111/deci.12408

Zhou K.Z. \& Li C.B. (2009). How knowledge affects radical innovation: Knowledge base, market knowledge acquisition, and internal knowledge. Strategic Management Journal, 33(3), 1090-1102. https://doi. org/10.1002/smj.1959

Erik Ružić, PhD, is an Associate Professor at the Faculty of Economics and Tourism "Dr. Mijo Mirković" in Pula, Croatia. His main fields of interest are sales management, personal selling and internal marketing. He used to work as a sales manager and has professional experience in different managerial positions.

Dragan Benazić, PhD, is an Associate Professor at the the Faculty of Economics and Tourism "Dr. Mijo Mirković" in Pula, Croatia. He is author and co-author of numerous scientific articles. His research is focused on the fields of marketing research, price management and services marketing. 